\title{
Impact of antifungals producing rhizobacteria on the performance of Vigna radiata in the presence of arbuscular mycorrhizal fungi
}

\author{
Deepti Dwivedi • Bhavdish N. Johri • Kurt Ineichen • \\ Victor Wray • Andres Wiemken
}

Received: 13 July 2008 / Accepted: 26 April 2009 /Published online: 21 May 2009

(C) Springer-Verlag 2009

\begin{abstract}
Plant growth-promoting rhizobacteria (PGPR) that produce antifungal metabolites are potential threats for the arbuscular mycorrhizal (AM) fungi known for their beneficial symbiosis with plants that is crucially important for low-input sustainable agriculture. To address this issue, we used a compartmented container system where test plants, Vigna radiata, could only reach a separate nutrientrich compartment indirectly via the hyphae of AM fungi associated with their roots. In this system, where plants depended on nutrient uptake via AM symbiosis, we explored the impact of various PGPR. Plants were inoculated with or without a consortium of four species of AM fungi (Glomus coronatum, Glomus etunicatum, Glomus constrictum, and Glomus intraradices), and one or more of the following PGPR strains: phenazine producing $\left(\mathrm{P}^{+}\right)$and phenazine-less mutant $\left(\mathrm{P}^{-}\right)$, diacetylphloroglucinol (DAPG) producing $\left(\mathrm{G}^{+}\right)$and DAPG-less mutant $\left(\mathrm{G}^{-}\right)$
\end{abstract}

\footnotetext{
D. Dwivedi • B. N. Johri

Department of Microbiology,

GB Pant University of Agriculture and Technology,

Pantnagar 263 145, Uttaranchal, India

D. Dwivedi $\cdot$ K. Ineichen $\cdot A$. Wiemken

Department of Botany, University of Basel,

Hebelstrasse 1,

4056 Basel, Switzerland

V. Wray

Department of Structural Biology,

Helmholtz Centre for Infection Research,

Inhoffenstraße 7,

38124 Braunschweig, Germany

D. Dwivedi $(\square)$

Laboratory of Molecular Genetics,

National Institute of Environmental and Health Sciences,

Research Triangle Park, NC 27709, USA

e-mail: dwivedid@niehs.nih.gov
}

strains of Pseudomonas fluorescens, and an unknown antifungal metabolite-producing Alcaligenes faecalis strain, SLHRE425 (D). PGPR exerted only a small if any effect on the performance of AM symbiosis. $\mathrm{G}^{+}$enhanced AM root colonization and had positive effects on shoot growth and nitrogen content when added alone, but not in combination with $\mathrm{P}^{+}$. D negatively influenced $\mathrm{AM}$ root colonization, but did not affect nutrient acquisition. Principal component analysis of all treatments indicated correlation between root weight, shoot weight, and nutrient uptake by AM fungus. The results indicate that antifungal metabolites producing PGPR do not necessarily interfere with AM symbiosis and may even promote it thus carefully chosen combinations of such bioinoculants could lead to better plant growth.

Keywords Antifungal-producing bacteria · PGPR . Mycorrhiza helper bacteria $\cdot$ AMF

\section{Introduction}

The rhizosphere is a dynamic environment harboring a large and diverse community of prokaryotic and eukaryotic microbes that interact with each other and with the plant root. One member of this community can affect the growth and physiology of the others, as well as the physical and chemical properties of the soil. The sum of these interactions influences not only plant mineral nutrient acquisition but also the tolerance of plants to adverse chemical soil conditions and susceptibility to diseases (Rainey 1999). In particular, one group of bacteria-collectively called plant growth-promoting rhizobacteria (PGPR) - can stimulate plant growth through direct or indirect interactions with roots (Kloepper 1993). Antagonistic PGPR suppress plant pathogens, through competition for carbon and nitrogen as 
nutrients or signals, competition for iron, preemptive competitive (niche) pathogen exclusion from favored sites of infection courts, and induction of systemic resistance or direct pathogen inhibition by antimicrobial compounds (antibiotics, hydrogen cyanide, etc.). Some PGPR can also directly stimulate plant growth by increasing the availability of mineral nutrients or the levels of phytohormones (Thomashow and Weller 1995; Whipps 2001; Haas and Keel 2003; Dwivedi and Johri 2003; Haas and Défago 2005; Raaijmakers et al. 2006; Weller et al. 2007; Rezzonico et al 2007). Strains of Pseudomonas fluorescens that produce the polyketide antibiotic 2,4-diacetylphloroglucinol (DAPG) are some of the most effective PGPR controlling root and seedling diseases. For example, $P$. fluorescens CHA0 suppresses black root rot of tobacco, crown and root rot of tomato, Pythium damping off of cucumber, and take all of wheat (Keel et al. 1992; SchniderKeel et al. 1995; Landa et al. 2002). In some soils, DAPG producers also play a key role in the natural suppression of take-all disease of wheat, known as take-all decline (Raaijmakers and Weller 1998; Raaijmakers et al. 1999; Haas and Défago 2005). Phenazine-1-carboxylic acid producing $P$. fluorescens 2-79 also suppresses take all of wheat by inhibiting Gaeumannomyces graminis var. tritici (Bull et al. 1991). Besides these bacteria, a group of fungi beneficial to plants, the arbuscular mycorrhizal (AM) fungi in the phylum Glomeromycota, form symbiotic associations with the roots of most terrestrial plants (Schussler et al. 2001; Toljander et al. 2006). The extraradical hyphae of the AM fungi explore the soil by an extended network, thereby increasing the nutrient absorption surface area of their host plant (Rhodes and Gerdemann 1975). Conversely, they also act as conduits for the transport of energy-rich assimilates from the plants to the soil microflora that may enhance unlocking of secluded mineral nutrients (Mäder et al. 2000; Hodge 2001; Oehl et al. 2003; Johnson et al. 2002; Toljander et al. 2006) and water acquisition (Ebel et al. 1996). It has been suggested that bacteria in the mycorrhizosphere influence the growth and establishment of AM fungi by stimulating spore germination (Xavier and Germida 2003) and root colonization (Budi et al. 1999). Moreover, it has been shown that these interactions are facilitated by the close proximity of bacteria to the fungus, but little is known about the influence of such associations in plants when different antifungal-producing bacteria interact with AM fungi. In addition, it has been shown that PGPR can invade and colonize the exterior and interior of AM fungal spores (Levy et al. 2003).

Any application of antagonistic antifungal-producing PGPR such as Pseudomonas spp. as biocontrol agents in the field requires particular attention because of the possibility that it may antagonize not only fungal phyto- pathogens but also the beneficial AM fungi (Barea et al. 1998; Vázquez et al. 2000; Gaur et al. 2004). Nevertheless, combinations of AM fungi and PGPR suitable as biocontrol agents and biofertilizers enhancing both plant health and growth may be found (Akköprü and Demir 2005). A mixed inoculum of pseudomonads and AM fungi has been reported to promote tomato growth due to improved $\mathrm{P}$ acquisition (Gamalero et al. 2004). Enhanced knowledge regarding the beneficial interactions of plants with AM fungi and PGPR is of special importance for low-input sustainable agriculture that relies on biological processes and resources, rather than on the use of agrochemicals for maintaining soil fertility and plant health (Smith and Read 1997; Artursson et al. 2006).

The aim of the present work was to investigate if the symbiotic performance of green gram, Vigna radiata (L.) R. Wilczek, with AM fungi is affected by bacteria that produce antifungal compounds, namely the phenazine-producing $P$. fluorescens 2-79, the DAPG producing $P$. fluorescens CHA0rif and their respective mutants deficient in the bacterium of these antifungals, and the Alcaligenes faecalis SLHRE 425 that was newly isolated from the wheat rhizosphere and produces an unknown antifungal compound. Phenazines are broad-spectrum antifungal compounds that are active against phytopathogenic fungi and other bacteria (Boronin and Thomashow 1998), whereas DAPG is a broad-spectrum antibiotic that exhibits antifungal, antibacterial, antihelmenthic, and phytotoxic activities (Haas and Défago 2005). Both groups of compounds have proved to be effective in suppressing Gaeumanomyces var. tritici, the cause of take-all disease of wheat (Schnider-Keel et al. 1995).

We have used a compartmented container system (Wyss et al. 1991) consisting of a root-free nutrient-rich middle compartment separated by a fine screen (30 $\mathrm{mm}$ mesh) from nutrient deficient side root compartments. Since the large compartment is accessible to the hyphae only, a large mycorrhiza dependency of the plants is expected, and thus, the impact of the PGPR on the AM symbiosis performance, if any, should be much more pronounced and more easily recognizable than in a simple pot system. While it is certainly also possible for nutrients to pass through the mesh walls into the plant compartments, experience has shown that such a transfer is generally negligible, in particular in the case of phosphorus, as compared to the more efficient transport of nutrients by means of the fungal hyphae. One factor underlying this phenomenon is the method by which the plants were watered. They are watered in the side compartments only, and hence, the mass flow of water is directed inward toward the central compartment, minimizing the outward transport of dissolved nutrients by mass flow. This allowed us to 
specifically study the influence of PGPR on AM functionality in terms of plant nutrient acquisition, root colonization, and soil microbial population structure in a laboratory setting (Mäder et al. 2000).

\section{Materials and methods}

\section{Container system}

The compartmented container system (Wyss et al. 1991) used in this study is illustrated in Fig. 1. The side compartments containing the test plants were inoculated or not with AM fungi (root hyphal compartment, RHC), while the middle compartment was accessible only to the fungal hyphae and not the plant roots (hyphal compartment, $\mathrm{HC})$ as it was separated from the RHC by a nylon screen (30 mm mesh; Zurcher Beuteluchfabrik, Ruschlikon, Switzerland) that could be penetrated by the AM hyphae but not by the roots. The RHC on both sides were further subdivided into five subcompartments, which allowed sampling of individual plants without disturbing neighboring ones.

\section{Microbial inoculants}

The bioinoculants used are listed in Table 1.

Microbial wash

All plants received a microbial wash containing an indigenous microbial population to maintain the natural microbial community in addition to the added inoculants.
The microbial wash was prepared from $60 \mathrm{~g}$ of indigenous wheat soil and, additionally, to ascertain the supply of compatible rhizobia, from $60 \mathrm{~g}$ of soil taken from pots in which green gram inoculated with its rhizobia had been grown. Each of these soil samples was stirred with $600 \mathrm{ml}$ sterile water until homogeneous soil suspensions were obtained; the suspensions were then filtered through Whatmann No. 1 paper holding back all AM fungal propagules. This soil filtrate, the microbial wash, was added at a ratio of filtrate from $1 \mathrm{~g}$ of soil per $1 \mathrm{~kg}$ of soil substrate.

\section{Culture conditions and soil inoculation}

Bacterial cultures were grown overnight in King's B medium (20 g Proteose peptone (Fluka, Switzerland), $1 \mathrm{~g}$ $\mathrm{K}_{2} \mathrm{HPO}_{4}, 0.4 \mathrm{~g} \mathrm{MgSO}_{4}, 8 \mathrm{ml}$ glycerol in 1,000 ml distilled water) at $28^{\circ} \mathrm{C}$ on a rotary shaker $(200 \mathrm{rpm})$. Cells were harvested by centrifugation for $10 \mathrm{~min}$ at $6,000 \times \mathrm{g}$ and resuspended in $0.85 \% \mathrm{NaCl}$. Following two washes with $0.85 \% \mathrm{NaCl}$, the cells were resuspended in sterile distilled water. The optical density of the suspension was measured in a spectrophotometer (Shimadzu, Japan) to quantify cell number (an $\mathrm{OD}_{600}$ of 0.125 corresponded to $10^{8}$ cells $/ \mathrm{ml}$ ). A volume of $1.25 \mathrm{ml}\left(0.4 \mathrm{OD}_{600}\right)$ of bacterial suspension was inoculated per $100 \mathrm{~g}$ of soil in each of the ten side compartments.

Mycorrhizal inoculum consisted of air-dried soil containing all four AM fungi (Table 1) in equal amounts (infective propagules) in the form of AM fungal hyphae, spores, and AM-colonized roots of Tagetes sp. in a mixture of equal volumes of quartz sand and Lecadan clay (Wyss et al 1991). A nutrient poor subsoil from Therwil, Switzerland
Fig. 1 The container system consisting of a central nutrientrich, hyphal compartment $(H C)$ plus a series of root hyphal compartment $(R H C)$ at both sides in which the test plants; $V$. radiata (L.) R. Wilczek, were grown in a nutrient deficient substrate. The compartments were separated by a $30-\mathrm{mm}$ nylon mesh, allowing the passage of AM hyphae, but preventing the passage of roots. $T C P$ tricalcium phosphate

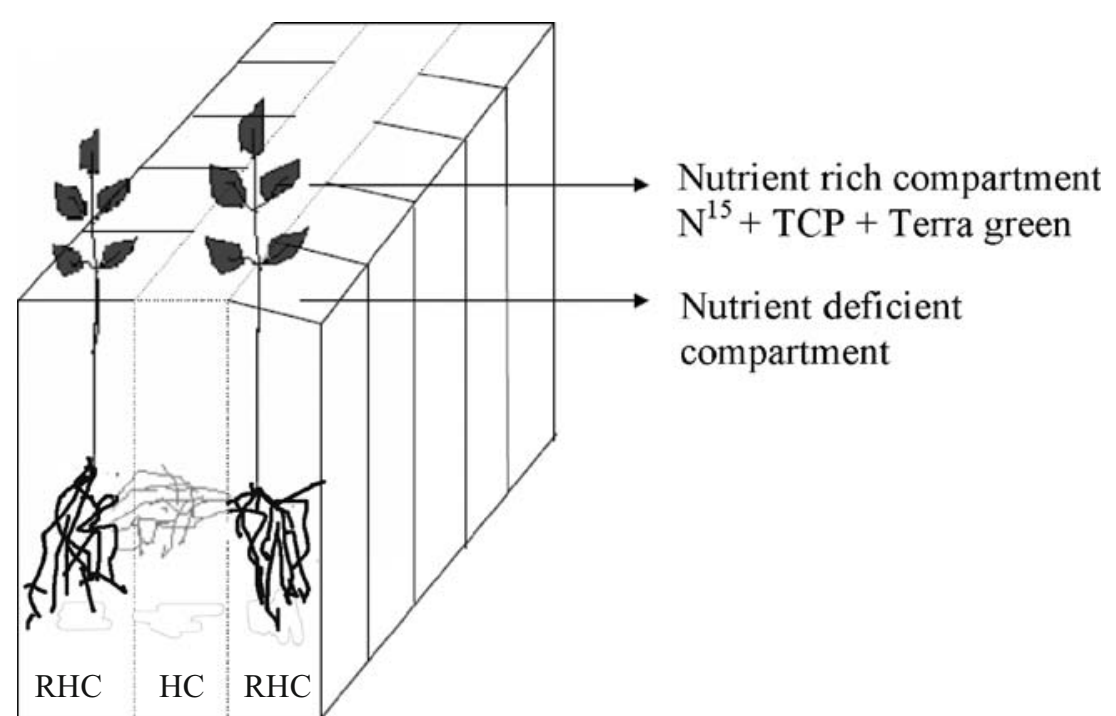


Table 1 The list of bioinoculants used in this study

\begin{tabular}{|c|c|c|}
\hline Inoculants used & Properties & $\begin{array}{l}\text { Abbreviations } \\
\text { used }\end{array}$ \\
\hline Pseudomonas fluorescens $2-79^{\mathrm{a}}$ & Phenazine producer & $\mathrm{P}^{+}$ \\
\hline Pseudomonas fluorescens 2-79 D::lacZ ${ }^{\mathrm{a}}$ & Phenazine negative mutant & $\mathrm{P}^{-}$ \\
\hline Pseudomonas fluorescens CHA0rif ${ }^{\text {a }}$ & DAPG producer & $\mathrm{G}^{+}$ \\
\hline Pseudomonas fluorescens $\mathrm{CHA} 630^{\mathrm{a}}$ & DAPG negative mutant & $\mathrm{G}^{-}$ \\
\hline Alcaligenes faecalis & Unknown antifungal producer, select isolate & $\mathrm{D}$ \\
\hline Consortium of all bacteria & $\mathrm{P}^{+} \mathrm{P}^{-} \mathrm{G}^{+} \mathrm{G}^{-} \mathrm{D}$ & $\mathrm{B}$ \\
\hline Glomus coronatum $^{\mathrm{b}}$, G. etunicatum ${ }^{\mathrm{b}}$, G. constrictum $^{\mathrm{c}}$, and $G$. intraradices $^{\mathrm{c}}$ & Mycorrhizal consortium $^{\mathrm{d}}$ & M \\
\hline
\end{tabular}

was homogenized by sieving $(2 \mathrm{~mm})$. This soil, washed quartz sand (Type K 30, size $0.2-0.5 \mathrm{~mm}$, Trafor $A G$, Basel, Switzerland), and Terragreen were autoclaved separately at $121^{\circ} \mathrm{C}$ overnight. All ten RHC on both sides of the compartmented units were filled with $100 \mathrm{~g}$ sand/soil mixture $(1: 1, w / w)$. In the $\mathrm{HC}$, the middle compartment, a mixture of $500 \mathrm{~g}$ containing Terragreen/sand/soil $(1: 1: 1, w /$ $w$ ), supplemented with $20 \mathrm{~g}{ }^{15} \mathrm{~N}$ manure + hay (Langmeier et al. 1998) and tricalcium phosphate (100 mg), was prepared and placed in the middle compartment. The compartment systems were saturated with (sterile) water by soaking them from the bottom, until the soil appeared wet at the top surface.

Green gram, V. radiata (L.) R. Wilczek, seeds were soaked with water on a wet tissue paper for $24 \mathrm{~h}$ to germinate. Four or five germinated seeds were planted into the side chambers, with $6 \mathrm{~g}$ of mycorrhizal inoculum and $1.25 \mathrm{ml}$ of bacterial suspension. Nonmycorrhizal controls received only the bacterial suspensions whereas mycorrhizal controls received only the mycorrhizal inoculum. In addition, $1 \mathrm{ml}$ aliquots of a microbial wash (refer as above) were applied to all compartments, to provide an equal general bacterial background population.

Nonmycorrhizal and mycorrhizal green gram plants were grown in the RHC. Each experiment consisted of eight treatments, with four replicates per treatment.

In each treatment, plants were fertilized six times per week with $3 \mathrm{ml}$ of one fifth of modified Hoagland solution without phosphorus by irrigation in the RHC. Full-strength modified Hoagland solution (Hoagland and Arnon 1950) was applied once per treatment to the saturation level in the middle chamber. The modified Hoagland's solution consisted of macroelements (per $\mathrm{ml}$ ) $0.5 \mathrm{~g} \mathrm{KNO}_{3}, 0.11 \mathrm{~g} \mathrm{Ca}\left(\mathrm{NO}_{3}\right)_{2} .4 \mathrm{H}_{2} \mathrm{O}, 0.13 \mathrm{~g} \mathrm{KH}_{2} \mathrm{PO}_{4}$,
$0.49 \mathrm{~g} \mathrm{MgSO}_{4} \cdot 7 \mathrm{H}_{2} \mathrm{O}$, and $0.2 \mathrm{~g}$ Sequestren (Fe-EDTA) and microelements (per $\mathrm{ml}$ ) $0.3 \mathrm{mg} \mathrm{MnSO}_{4} .1 \mathrm{H}_{2} \mathrm{O}$, $\mathrm{ZnSO}_{4} .7 \mathrm{H}_{2} \mathrm{O}, 0.04 \mathrm{mg} \mathrm{CuSO} \mathrm{CH}_{2} .5 \mathrm{H}_{2} \mathrm{O}, 1 \mathrm{mg}$ $\mathrm{Na}_{2} \mathrm{~B}_{4} \mathrm{O}_{7} .10 \mathrm{H}_{2} \mathrm{O}$, and $0.05 \mathrm{mg}\left(\mathrm{NH}_{4}\right)_{6} \mathrm{Mo}_{7} \mathrm{O}_{2}$.

Plants were grown in a green house from mid-May to mid-August (13 weeks), at a temperature between $18^{\circ} \mathrm{C}$ and $25^{\circ} \mathrm{C}$. Supplementary light was used to extend the day length to $14 \mathrm{~h}$. The position of growth containers in the glasshouse was rerandomized at 3 days intervals.

\section{Sampling strategy}

Total roots from two plants of each of four replicates were cut and shaken gently to remove adhered soil particles. The roots were weighed, and the shoots were dried in an oven at $80^{\circ} \mathrm{C}$ for 2 days. Roots $(0.5 \mathrm{~g})$ were crushed in $10 \mathrm{ml}$ of water and serially diluted up to $10^{-6}$ for plating. The remaining root fraction was washed with tap water, pat-dried with tissue paper, weighed, and cut into $1 \mathrm{~cm}$ pieces and kept for mycorrhizal root staining in $0.1 \% \mathrm{KOH}$ overnight. Plants were harvested 13 weeks after planting when they were at fruiting stage.

\section{Mycorrhizal root staining}

The root staining method that was modified by Phillips and Hayman (1970) was used. A weighed fresh root sample from each treatment was stained with trypan blue in lactophenol according to Phillips and Hayman (1970). The percentage of root length colonization by AM fungi was determined microscopically using the gridline intersection method of Giovannetti and Mosse (1980). 
Nutrient analysis

The uptake of nutrients, mainly phosphorus and nitrogen, is greatly aided by mutualistic associations with AM fungi. These fungi extend long hyphal threads outside the roots transporting phosphorus and other nutrients into the plant roots. In order to follow the uptake, we supplied ${ }^{15} \mathrm{~N}$ in the nutrient-rich middle compartment as well as phosphorus-rich terra green and tricalcium phosphorus such that the fungal hyphae could extend from the side compartment into the middle compartment and thus provide nutrients to the roots of the plants growing in the side compartments.

\section{Analysis of phosphorus content}

Dry shoot matter was milled, digested, and analyzed for $\mathrm{P}$ content using the method of Watanabe and Olsen (1965) and Onishi et al. (1975).

\section{Analysis of nitrogen and ${ }^{15} \mathrm{~N}$ content}

Shoots were ground to a fine powder using a ball mill, and total $\mathrm{N}$ content was measured using a Leco $\mathrm{CHN}$ analyzer. ${ }^{15} \mathrm{~N}$ was determined by mass spectrophotometry using the ANCA-SL/GSL at the Analytical Service of Europa Scientific Ltd., Crewe, UK. ${ }^{15} \mathrm{~N}$ enrichments of green gram shoots were calculated by subtracting the natural ${ }^{15} \mathrm{~N}$ abundance control $(0.366 \%)$.

\section{Statistical analysis}

There were four replicates per treatment with two plants per container system, giving a total of 32 assemblies, in a randomized block. Treatments were analyzed by oneway analysis of variance. Differences were considered as statistically significant at $P<0.05$. Total performance of the green gram plants in response to different treatments was analyzed with principal component analysis (PCA) with the use of the statistical package Plus 6.1 software (Insightful Corp., USA). The PCA plot with correlation scaling was used to analyze the relationship between the different treatments and the different plant attributes. In this analysis, the treatments are defined as the objects and the different plant attributes as the descriptors (represented by the vectors) of the multivariate analysis. Since descriptors were measured in different units, they were standardized before the analysis. The PCA is presented as a two-dimensional correlation plot (Fig. 7).

\section{Results}

Effect of mycorrhiza on the Pseudomonas population

The mycorrhizal control, $\mathrm{M}$, had a significantly higher population than $P$. fluorescens 2-79 D::lacZ-treated mycorrhizal plants $\left(\mathrm{MP}^{-}\right)$. There was no significant difference in the total pseudomonad population for other treatments. However, all mycorrhiza (M)-treated bacterial plants: SLHRE425 (D), P. fluorescens 2-79 $\left(\mathrm{P}^{+}\right)$, P. fluorescens CHA0 $\left(\mathrm{G}^{+}\right)$, P. fluorescens CHA0rif $\left(\mathrm{G}^{-}\right)$, and $\mathrm{P}^{+} \mathrm{G}^{+}$had lower colony forming units than nonmycorrhizal bacterial control treatments, B (Fig. 2). The nonmycorrhizal control, $\mathrm{B}$, had maximum counts $\left(2.21 \pm 0.21 \times 10^{8}\right)$. The lowest counts were observed for MD $\left(2.93 \times 10^{7} \pm 2.03\right.$ cells $/ g$ of soil; Fig. 2).

\section{Effect of treatments on plant growth}

The root fresh weight was significantly highest in $\mathrm{MG}^{+}$ plants, compared to $\mathrm{MG}^{-}$plants as well as compared to the rest of the treatments and the nonmycorrhizal control (Fig. 3a). The values of root dry weight were not significantly different for the remaining treatments.

$\mathrm{MG}^{+}$plants had a significantly higher shoot dry weight than the $\mathrm{MP}^{+}, \mathrm{MD}$, and the $\mathrm{MP}^{+} \mathrm{G}^{+}$consortium plants. The shoot dry weights of $\mathrm{MP}^{+}$and $\mathrm{MP}^{+} \mathrm{G}^{+}$were significantly

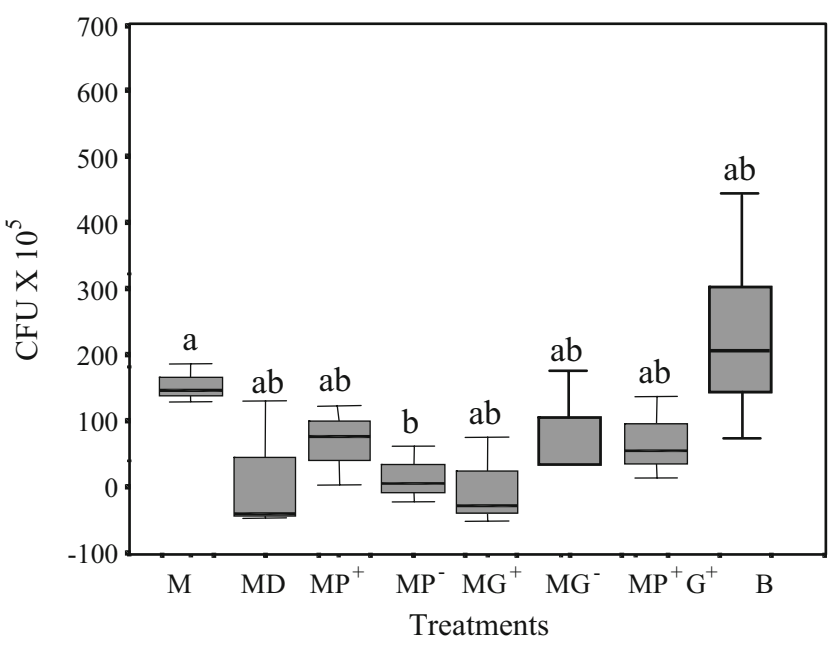

Fig. 2 The effect of mycorrhiza on the development of various antifungal-producing PGPR populations in the green gram ( $V$. radiata) rhizosphere established after a plant growth period of 13 weeks in the root hyphal compartment. $M$ plants with mycorrhiza only, $D$ (SLHRE425; unknown antifungal producer), $P^{+}\left(2-79 ; \mathrm{Phz}^{+}\right), P^{-}$ (2-79 D::lacZ; $\left.\mathrm{Phz}^{-}\right), G^{+}$(CHA0rif; $\left.\mathrm{DAPG}^{+}\right), G^{-}$(CHA630; $\mathrm{DAPG}^{-}$), $B$ (all bacteria). Box plots indicate median values (lines in boxes), 75th and 25th percentiles (limits of the box). Upper and lower horizontal bars indicate 10th and 90th percentiles, respectively. $C F U$ colony forming units. Different lowercase letters above boxes indicate a significant difference between treatments $(P<0.05, n=4)$ 
Fig. 3 The effect of different antibiotic metabolite-producing bacteria on the growth of mycorrhizal green gram plants grown for 13 weeks in root hyphal compartment. Root fresh weight (a) and shoot dry weight (b) of two plants per container system. $M$ plants with mycorrhiza only, $D$ (SLHRE425; unknown antifungal producer), $P^{+}$(2-79; $\mathrm{Phz}^{+}$), $P^{-}$(2-79 D::lacZ; $\mathrm{Phz}^{-}$), $G^{+}$(CHA0rif; DAPG $\left.{ }^{+}\right), G^{-}$ (CHA630; DAPG $^{-}$), $B$ (all bacteria). The error bars represent standard errors of means of root and shoot weight, respectively $(n=4)$. Different lowercase letters above the bars indicate significant differences between the treatments $(P<0.05)$
(A)

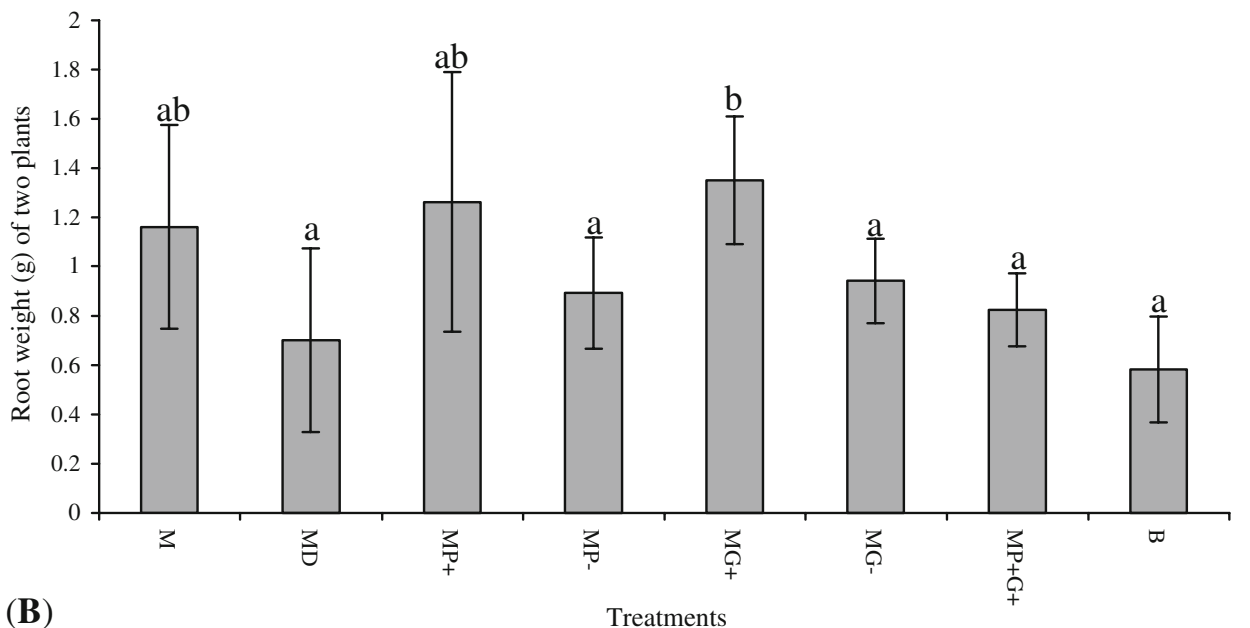

(B)

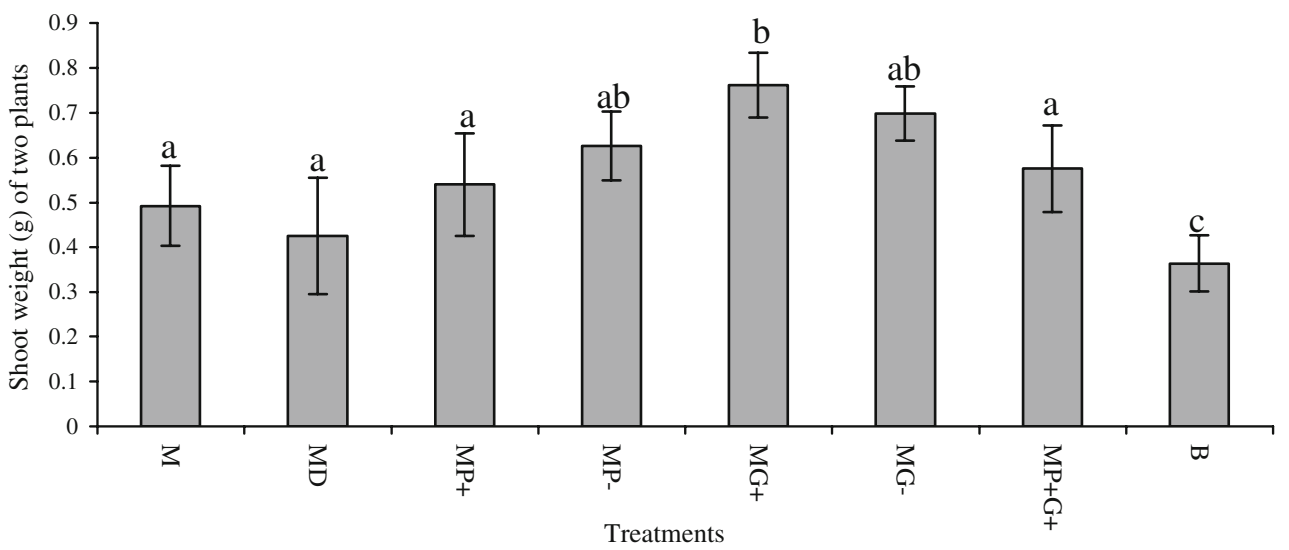

higher than that of the nonmycorrhizal control, B, although it was not significantly different from $\mathrm{M}$. There was no significant difference in shoot dry weight of green gram plants versus the other treatments (Fig. 3b).

\section{Effect on mycorrhizal colonization}

$\mathrm{MG}^{+}$had a highly significant positive influence on mycorrhizal colonization (average of $67.75 \%$; Fig. 4) as compared to $\mathrm{MG}^{-}$and other treatments. The vesicles and arbuscules were also observed in higher numbers (data not shown). In contrast, $\mathrm{MG}^{-}$and $\mathrm{MD}$ gave significantly lower percentages of mycorrhizal colonization of $34.5 \%$ and $28.41 \%$, respectively. $\mathrm{MP}^{+}$also resulted in significantly lower percentage of mycorrhizal colonization $(40.75 \%)$ compared to $\mathrm{MG}^{+}$but there was no significant difference to the mycorrhizal control, $\mathrm{M}(44.32 \%)$. Interestingly. $\mathrm{MP}^{+} \mathrm{G}^{+}$ consortium inoculated plants had a reduced mycorrhization as compared to the individually inoculated $\mathrm{MP}^{+}$and $\mathrm{MG}^{+}$ plants. MD had significantly lower mycorrhizal colonization $(28.42 \%)$.
Effect on nutrient content (nitrogen and phosphorus) in plant shoots

$\mathrm{MG}^{+}$and $\mathrm{MP}^{+}$plants had a significantly higher $\mathrm{P}$ content than $\mathrm{MD}$. The consortium $\mathrm{MP}^{+} \mathrm{G}^{+}$induced a significantly decreased $\mathrm{P}$ content compared to four of the individually inoculated mycorrhizal plants (Fig. 5). The nonmycorrhizal control (B) had significantly lower P content compared to all mycorrhizal plants with the exception of the $\mathrm{MP}^{+} \mathrm{G}^{+}$ plants (Fig. 5).

$\mathrm{MG}^{+}$had a significantly higher $\mathrm{N}$ content than $\mathrm{MP}^{+}$ (Fig. 6a) although it was not significantly different from $\mathrm{MG}^{-}$and $\mathrm{MP}^{-}$. $\mathrm{MP}^{+} \mathrm{G}^{+}$consortium had significantly lower $\mathrm{N}$ content than $\mathrm{MG}^{+} . \mathrm{MG}^{+}$and $\mathrm{MG}^{-}$had significantly higher $\mathrm{N}$ contents compared to all other treatments except to $\mathrm{MP}^{-}$. Nonmycorrhizal control and mycorrhizal controls were nonsignificantly different from each other. MD had a significantly lower $\mathrm{N}$ content than $\mathrm{MP}^{+}$and $\mathrm{MG}^{+}$(Fig. 6a).

$\mathrm{MG}^{+}$had a significantly higher $\mathrm{N}^{15}$ content than $\mathrm{MP}^{+}$, $\mathrm{MD}$, and mycorrhizal control $\mathrm{M} . \mathrm{MP}^{+} \mathrm{G}^{+}$consortium had a significantly lower $\mathrm{N}$ content than $\mathrm{MG}^{+}$. Moreover, the 


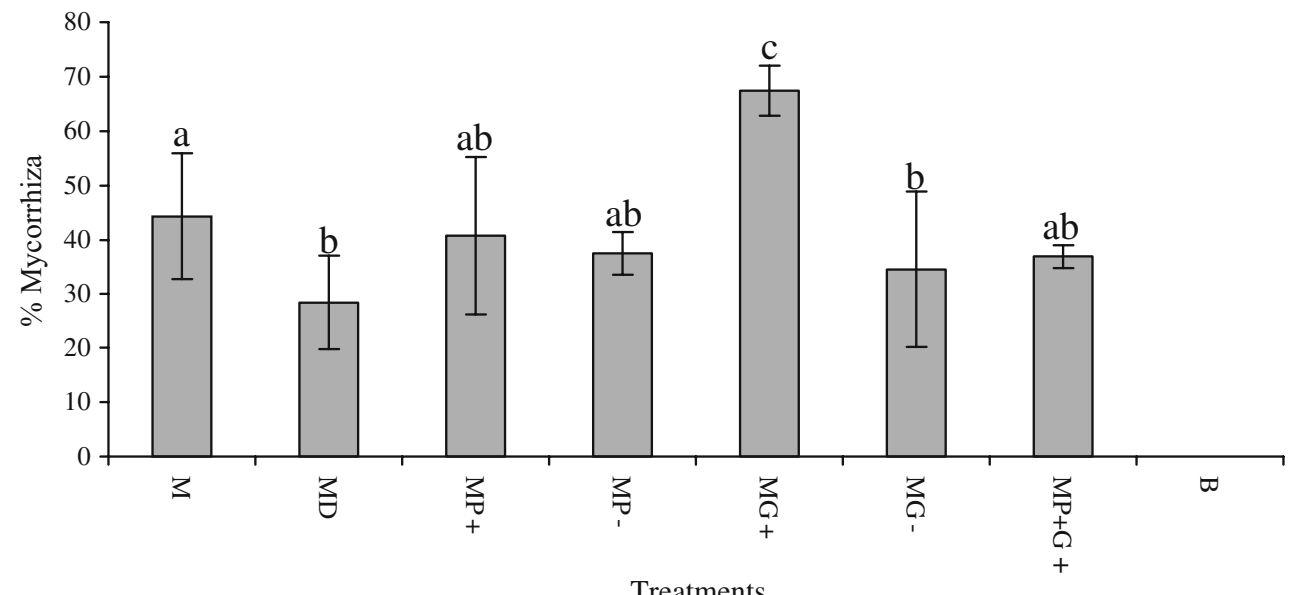

Fig. 4 The percent mycorrhizal colonization of green gram roots grown for 13 weeks in a root hyphal compartment. $M$ plants with mycorrhiza only, $D$ (SLHRE425; unknown antifungal producer), $P^{+}$ (2-79; $\left.\mathrm{Phz}^{+}\right), P^{-}$(2-79 D::lacZ; $\left.\mathrm{Phz}^{-}\right), G^{+}\left(\mathrm{CHA0rif}^{\mathrm{DAPG}}{ }^{+}\right), G^{-}$

nonmycorrhizal control $\mathrm{B}$ had a significantly lower $\mathrm{N}^{15}$ content than rest of the treatments except mycorrhizal control M and MD (Fig. 6b).

\section{Principal component analysis}

In order to determine the effects of various treatments and the correlation of different functional parameters with each other, principal component analysis with correlation scaling was performed and is shown in Fig. 7 as a two-dimensional plot (Pielou 1984; Garland and Mill 1991; Legendre and Legendre 1998). The first component or principal axis accounts for $69.4 \%$ whereas the second component or axis
(CHA630; DAPG ${ }^{-}$), $B$ all bacteria. Error bars represent standard errors of means of percent mycorrhiza, respectively $(n=4)$. Different lowercase letters above the bars indicate significant differences between the treatments $(P<0.05)$

is $18.61 \%$. The vectors representing ${ }^{15} \mathrm{~N}$ content, $\mathrm{N}$ content, and shoot weight were oriented in the same direction and were significantly positively correlated. The vectors for three other factors, $\mathrm{P}$ content, root weight, and \% mycorrhization were positively correlated with each other. Moreover, $\mathrm{MP}^{+}$treatment was positively associated with these factors. $\mathrm{MG}^{+}$treatment was associated positively with all factors. Indeed, the orthogonal projection of an object (treatment) on to a descriptor (vector representing different plant attributes) allows an assessment of the correlation between the object and the descriptor. Thus P. fluorescens CHA0rif $\left(\mathrm{G}^{+}\right)$act as mycorrhiza enhancing bacteria. It seems that DAPG had a beneficial impact affording

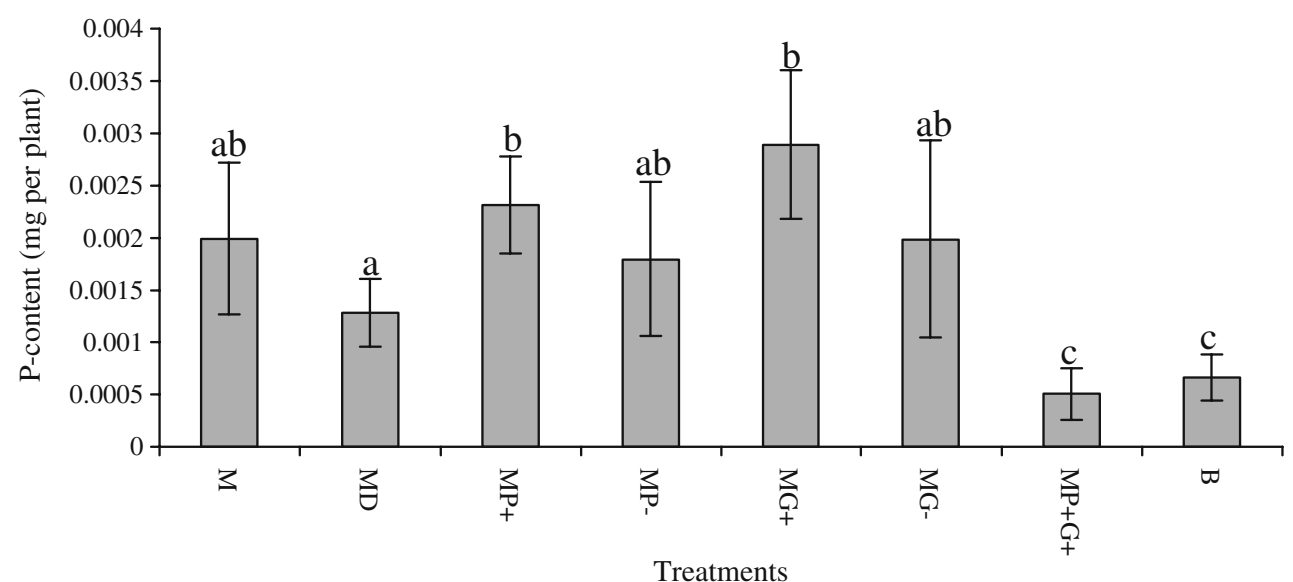

Fig. 5 The effect of different antibiotic metabolite-producing bacteria on the phosphorus content of shoots of green gram plants grown for 13 weeks in root hyphal compartments. $M$ plants with mycorrhiza only, $D$ (SLHRE425; unknown antifungal producer), $P^{+}\left(2-79 ; \mathrm{Phz}^{+}\right)$, $P^{-}$(2-79 D::lacZ; $\left.\mathrm{Phz}^{-}\right), G^{+}$(CHA0rif; DAPG $\left.{ }^{+}\right), G^{-}$(CHA630;
$\mathrm{DAPG}^{-}$), $B$ all bacteria. The error bars represent standard errors of means of $\mathrm{P}$ content, respectively $(n=4)$. Different lowercase letters above the bars indicate significant differences between the treatments $(P<0.05)$ 
Fig. 6 The effect of different antibiotic metabolite-producing bacteria on the $\mathrm{N}$ content of shoots of green gram plants grown for 13 weeks in root hyphal compartments a $\mathrm{N}$ content and $\mathbf{b}{ }^{15} \mathrm{~N}$ content. The error bars represent standard errors of means of $\mathrm{N}$ content, respectively $(n=4) . M$ plants with mycorrhiza only, $D$ (SLHRE425;

unknown antifungal producer), $P^{+}\left(2-79 ; \mathrm{Phz}^{+}\right), P^{-}(2-79 \mathrm{D}::$ lacZ; $\left.\mathrm{Phz}^{-}\right), G^{+}$(CHA0rif; $\left.\mathrm{DAPG}^{+}\right), G^{-}$(CHA630; $\left.\mathrm{DAPG}^{-}\right), B$ all bacteria. The error bars represent standard errors of means of $\mathrm{N}$ content, respectively $(n=4)$. Different lowercase letters above the bars indicate significant differences between the treatments $(P<0.05)$

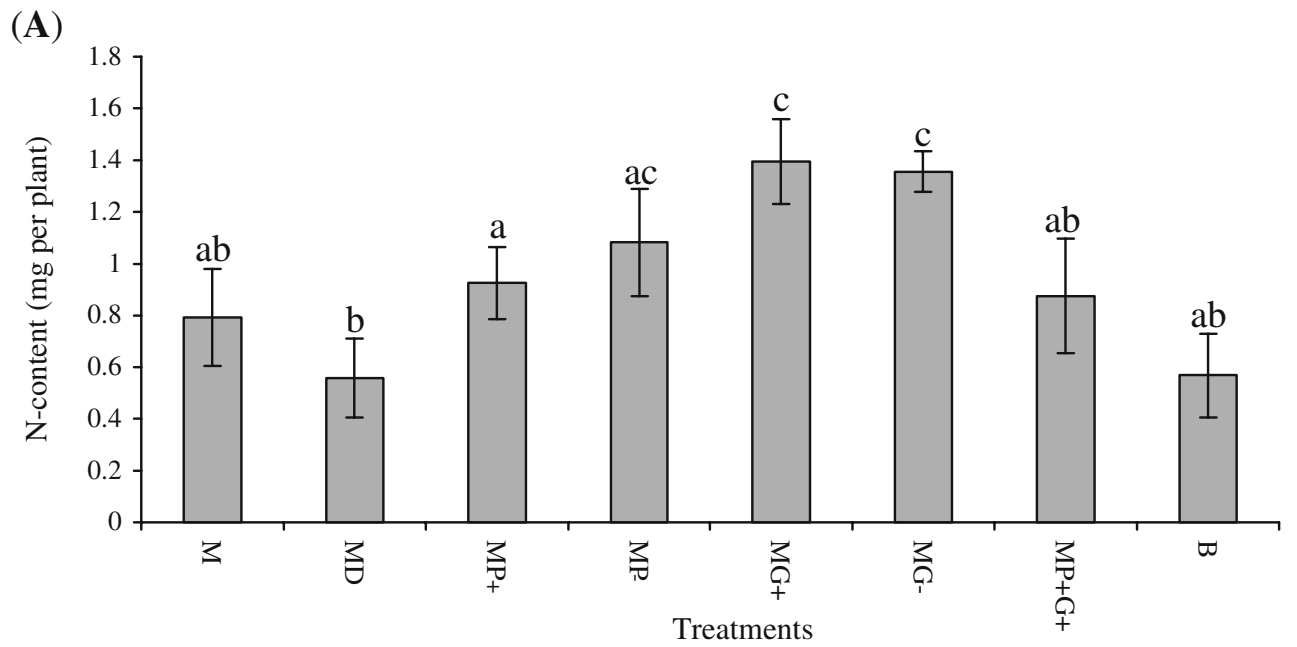

(B)

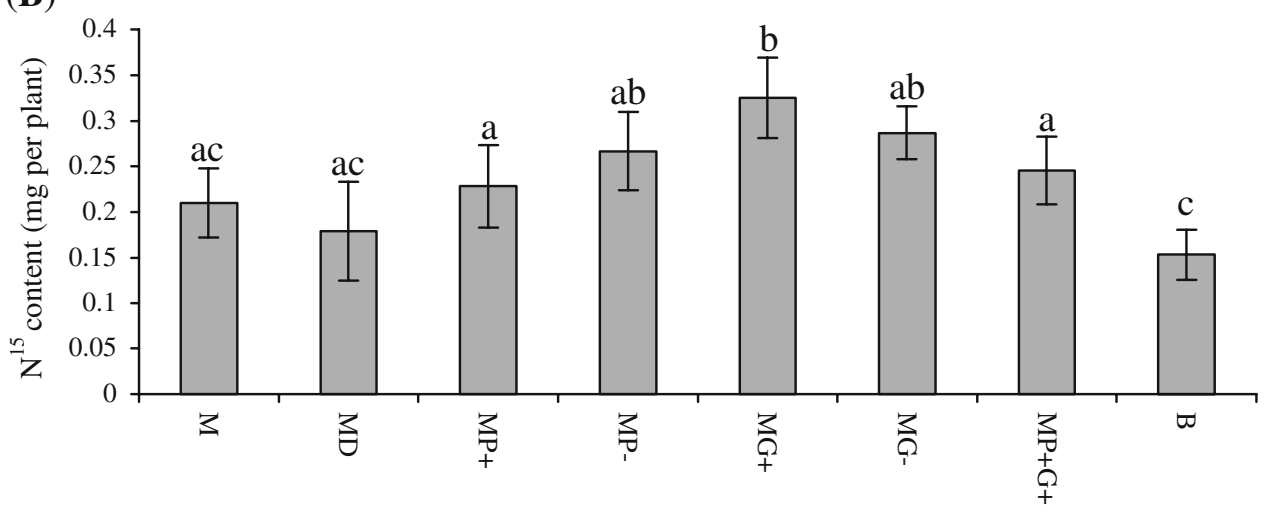

Treatments increased plant weight, mycorrhization, and nutrient content. Similarly, phenazine production does not have a deleterious effect on mycorrhizal fungi and benefited plant growth. In contrast, the $\mathrm{MD}$ and $\mathrm{MP}^{+} \mathrm{G}^{+}$treatments had the least effect upon \% mycorrhization, root weight, $\mathrm{P}$ content, $\mathrm{N}$ content, and shoot weight.

\section{Discussion}

The comparative study of antifungal metabolite-producing bacteria suggests that mycorrhizal-rhizobacterial interactions could bring about subtle changes in the mycorrhizosphere. In the present work, total pseudomonad count was higher in nonmycorrhizal control treatment suggesting a suppressive impact of the AM symbiosis on the bacterial population. Various reports have indicated an influence of AM symbiosis on the microbial community structure in the rhizosphere (Meyer and Linderman 1986a, b; Schreiner et al. 1997; Ravnskov et al. 1999; Linderman 2000). Paulitz and Linderman (1989) found a decrease in numbers of $P$. fluorescens in the rhizosphere of cucumber in the presence of Glomus intraradices and Glomus etunicatum.
Plants were most benefited when they were treated with both PGPR and mycorrhiza. This was best visualized through PCA that indicates the degree to which plant attributes were affected by various treatments (Fig. 7). There were positive correlations within the treatments for mycorrhizal colonization, $\mathrm{P}$ content, and root weight. $\mathrm{N}$ content, ${ }^{15} \mathrm{~N}$ content, and shoot weight were also positively correlated with each other. This again indicates that nutrient uptake increases concomitantly with better mycorrhizal colonization.

AM colonization was greatly affected by a change in the microbial population. "Mycorrhiza-helper bacteria" (MHB) have been described for the ectomycorrhizal symbiosis (Garbaye 1994) and only a few examples of MHB have been reported for the AM symbiosis (Toro et al. 1997; Singh and Kapoor 1998). The mechanisms by which these bacteria stimulate AM colonization are still poorly understood, but certain bacterial activities, such as the production of metabolites increasing root cell permeability and hormone synthesis, are expected to be involved (Barea et al. 1998). Meyer and Linderman (1986a, b) have previously emphasized that pseudomonads in the rhizosphere are a diverse group of bacteria and their interactions with plants 


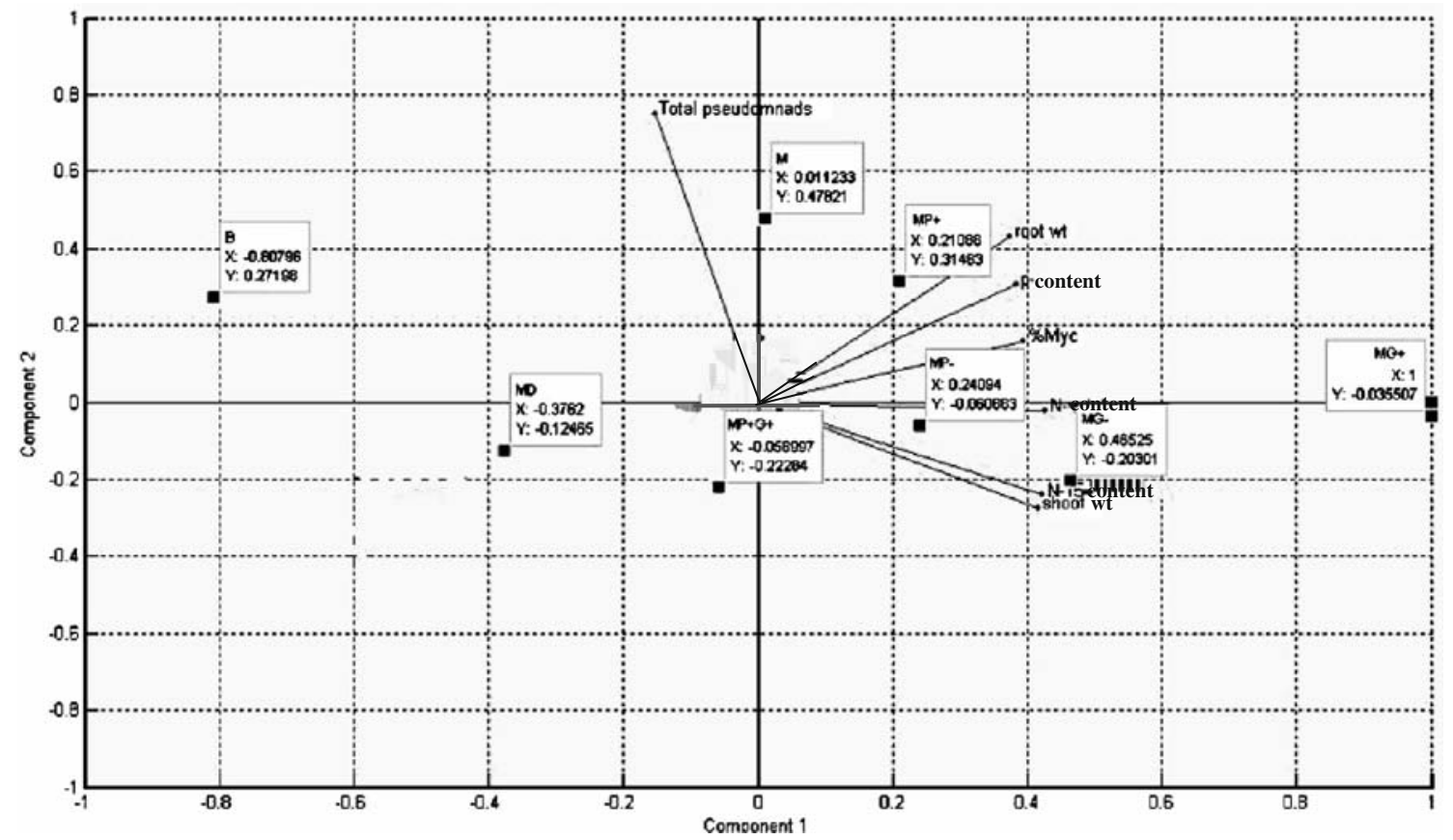

Fig. 7 Principal component analysis (correlation scaling) of all of the samples. It was performed using Matlab 7.0.1. The plant data were normalized before the analysis. Descriptors (arrows) indicate the shoot weight, ${ }^{15} \mathrm{~N}$ content, \% mycorrhization, $\mathrm{P}$ content, $\mathrm{N}$ content, root weight, and total pseudomonad count and objects are the treatments.

and mycorrhizal fungi will differ between strains, e.g., Bowen and Theodorou (1979) observed a fluorescent pseudomonad markedly suppressing the development of several ectomycorrhizal fungal species in Pinus roots. Mycorrhizal root colonization was significantly stimulated by $\mathrm{G}^{+}$which has also been previously found using various other bacteria (Azcón-Aguillar and Barea 1995; Barea et al. 1998; Vosátka and Gryndler 1999; Duponnois and Plenchett 2003). DAPG production appears to have a positive influence on mycorrhization as the DAPG negative mutant $\mathrm{G}^{-}$induced a significantly decreased AM colonization. $\mathrm{G}^{+}$has been reported to act as MHB (Garbaye 1994; Frey-Klett et al. 1997) exerting a positive effect on mycorrhizal associations. $\mathrm{P}^{+}$brought about a significant decrease in $\mathrm{AM}$ colonization compared to $\mathrm{MG}^{+}$but a nonsignificant one compared to the mycorrhizal control (M) indicating that its influence was noninhibitory. The mutant $\left(\mathrm{P}^{-}\right)$, however, induced a significantly reduced AM colonization. Also, MD had a negative effect on AM colonization. Interestingly, the consortium $\mathrm{MP}^{+} \mathrm{G}^{+}$induced a decreased colonization. DAPG producer, $\mathrm{G}^{+}$, alone stimulated mycorrhizal colonization but had no such impact when inoculated with the phenazine producer, $\mathrm{P}^{+}$, indicating a suppressive effect of the latter one. This indicates that antifungalproducing PGPR can behave as MHB but if there is an excessive antifungal pressure in the rhizosphere, a negative influence on the mycorrhization might occur.
$M$ plants with mycorrhiza only, $D$ (SLHRE425; unknown antifungal producer), $P^{+}$(2-79; $\left.\mathrm{Phz}^{+}\right), P^{-}$(2-79 D::lacZ; $\left.\mathrm{Phz}^{-}\right), G^{+}$(CHA0rif; $\left.\mathrm{DAPG}^{+}\right), G^{-}$(CHA630; $\left.\mathrm{DAPG}^{-}\right), B$ average value of all bacterial single controls, $P C 1$ principal component axis $1, P C 2$ principal component axis 2

All pseudomonad isolates singly inoculated had a positive impact on $\mathrm{P}$ content of the mycorrhizal plants compared to inoculation as consortium as well as to the singly inoculated $A$. faecalis treatment. The beneficial effect of AM fungi on plants for nutrient acquisition has been well documented (Duponnois and Plenchett 2003; Govindarajulu et al. 2005) and recently, it has been suggested that in AM symbiosis, plants receive all their phosphorus via fungal symbionts (Harrison 2005). AM fungi and phosphorous solubilizing rhizobacteria could also have a synergistic effect on plant growth as reported previously (Linderman 1988; Barea and Jeffries 1995). Increased plant P content has also been ascribed to a release of plant hormones by rhizobacteria (Azcón et al. 1976), continuous release of $\mathrm{PO}_{4}{ }^{-}$ions by phosphate-solubilizing pseudomonads, and subsequent uptake by AM fungi (Toro et al. 1997). Since $A$. faecalis (D) is a nonphosphorus solubilizer, there was no such synergistic effect on $\mathrm{P}$ content. It is intriguing to note that the $\mathrm{P}$ content in $\mathrm{MP}^{+} \mathrm{G}^{+}$consortium-treated plants was much smaller than in the other treatments of the mycorrhizal plants, a phenomenon that could be due the impact of the bacterial consortium in the mycorrhizosphere. It further indicates that for application, the right selection of bioinoculants is essential.

Higher shoot nitrogen contents in the $\mathrm{G}^{+}$-treated mycorrhizal green gram plants, compared to the nonmycorrhizal and mycorrhizal controls, demonstrate the close relation- 
ship between $\mathrm{AM}$ colonization and $\mathrm{N}$ content. This increased $\mathrm{N}$ content in the $\mathrm{MG}^{+}$plants might be due to the access of the plants to the nutrient-rich middle compartment via their associated AM fungi. However, unlike in the case of the plant $\mathrm{P}$ content, no such an increase in $\mathrm{N}$ content was found in the other treatments of the mycorrhizal plants. This could be due to the soil filtrate, which was added to ensure the presence of a native bacterial population that also included the appropriate rhizobia. This was done to provide the natural rhizospheric conditions to the plants. Rhizobia, by way of nitrogen fixation in the nodule symbiosis, are known to provide nitrogen to the plants and this capability is enhanced when plants are colonized by AM fungi (Ianson and Linderman 1993; Barea et al. 2002). It seems logical therefore that all mycorrhizal and nonmycorrhizal treatments did not have much difference in nitrogen uptake due to direct nitrogen fixation in the nodules. $\mathrm{MG}^{+}$might have facilitated nitrogen uptake because of the enhanced root mycorrhization.

In summary, the CHA0rif $\left(\mathrm{G}^{+}\right)$treatment had a stimulatory effect on mycorrhizal root colonization probably due to the DAPG production. P. fluorescens 2-79 $\left(\mathrm{P}^{+}\right)$did not exert antifungal action against the different AM fungi used in this study. The consortium of both these bacteria induced a decreased AM colonization and plant $\mathrm{P}$ content compared to their single treatments. Hence, it indicates that even if the PGPR strains improve plant growth individually, they may not necessarily do so when other strains are present. This demonstrates the complex relationships between microorganisms and, as a consequence, the difficulties in preparing an efficient bacterial consortium for biofertilization products. On the basis of these observations and considering the importance of both rhizobacteria and rhizofungi, the release of microbial bioinoculants that produce antifungal metabolites deserves a more detailed analysis to determine possible interference with the performance of AM fungi.

Acknowledgments The authors would like to thank Alok Adholeya for providing some mycorrhizal inocula; Geneviéve Défago and Linda Thomashow for providing the Pseudomonas cultures; and David Roesti, Feng He, and Bharani Kumar for statistical analysis and interpretation. We thank Roel M. Schaaper, Rajesh Kasiviswanathan, and Greg Stuart for critical comments on the manuscript. This work was funded by Indo-Swiss Collaboration in Biotechnology (ISCB).

\section{References}

Akköprü A, Demir S (2005) Biological control of Fusarium wilt in tomato caused by Fusarium oxysporum f. sp. lycopersici by AMF Glomus intraradices and some rhizobacteria. J Phytopathol 153:544-550. doi:10.1111/j.1439-0434.2005.01018.x

Artursson V, Finlay RD, Jansson JK (2006) Interactions between arbuscular mycorrhizal fungi and bacteria and their potential for stimulating plant growth. Environ Microbiol 8:1-10. doi:10.1111/j.1462-2920.2005.00942.x

Azcón R, Barea JM, Hayman DS (1976) Utilization of rock phosphate in alkaline soils by plants inoculated with mycorrhizal fungi and phosphate solubilizing bacteria. Soil Biol Biochem 8:135-138. doi:10.1016/0038-0717(76)90078-X

Azcón-Aguillar C, Barea JM (1995) Saprophytic growth of arbuscular-mycorrhizal fungi and other rhizospheric microorganisms. In: Allen MJ (ed) Mycorrhizal functioning: an integrative plant fungal process. Chapman and Hall, New York, N.Y, pp 163198

Barea JM, Jeffries P (1995) Arbuscular mycorrhiza in sustainable soil plant systems. In: Hock B, Varma A (eds) Mycorrhiza structure, function, molecular biology and biotechnology. Springer, Heidelberg, pp 521-559

Barea JM, Andrade G, Bianciotto D, Lohrke S, Bonfante P, O`Gara F, Azcon-Aguillar C (1998) Impact on arbuscular mycorrhiza formation of Pseudomonas strains used as inoculants for biocontrol of soil-borne fungal plant pathogens. Appl Environ Microbiol 64:2304-2307

Barea JM, Azcon R, Azcon-Aguilar C (2002) Mycorrhizosphere interactions to improve plant fitness and soil quality. Anton Leeuw Int J G 81:343-351. doi:10.1023/A:1020588701325

Boronin AM, Thomashow LS (1998) A seven gene locus for synthesis of phenazine-1-carboxylic acid by Pseudomonas fluorescens 279. J Bacteriol 180:2541-2548

Bowen GD, Theodorou C (1979) Interactions between bacteria and ectomycorrhizal fungi. Soil Biol Biochem 11:119-126. doi:10.1016/0038-0717(79)90087-7

Budi SW, van Tuinen D, Martinotti G, Gianinazzi S (1999) Isolation from the Sorghum bicolor mycorrhizosphere of a bacterium compatible with arbuscular mycorrhiza development and antagonistic towards soilborne fungal pathogens. Appl Environ Microbiol 65:5148-5150

Bull CT, Weller DM, Thomashow LS (1991) Relationship between root colonization and suppression of Gaeumannomyces graminis var. tritici by Pseudomonas fluorescens strain 2-79. Phytopathology 81:954-959. doi:10.1094/Phyto-81-954

Duponnois R, Plenchett C (2003) A mycorrhizal bacterium enhances ectomycorrhizal and endomycorrhizal symbiosis of Australian Acacia species. Mycorrhiza 13:85-91

Dwivedi D, Johri BN (2003) Antifungals from fluorescent pseudomonads: biosynthesis and regulation. Curr Sci 85:1693-1703

Ebel RC, Welbaum GE, Gunatilaka M, Nelson T, Auge RM (1996) Arbuscular mycorrhizal symbiosis and nonhydraulic signalling of soil drying in Vigna unguiculata (L.) Walp. Mycorrhiza 6:119127. doi: $10.1007 / \mathrm{s} 005720050116$

Frey-Klett P, Pieratt JC, Garbaye J (1997) Location and survival of mycorrhiza helper Pseudomonas fluorescens during establishment of ectomycorrhizal symbiosis between Laccaria bicolor and Douglas fir. Appl Environ Microbiol 63:139-144

Gamalero E, Trotta A, Massa N, Copetta A, Martinotti MG, Berta G (2004) Impact of two fluorescent pseudomonads and an arbuscular mycorrhizal fungus on tomato plant growth, root architecture and $\mathrm{P}$ acquisition. Mycorrhiza 14:185-192. doi:10.1007/s00572-003-0256-3

Garbaye J (1994) Helper bacteria: a new dimension to the mycorrhizal symbiosis. New Phytol 128:197-210. doi:10.1111/j.14698137.1994.tb04003.x

Garland JL, Mill AL (1991) Classification and characterization of heterotrophic microbial communities on the basis of patterns of community level sole carbon source utilization. Appl Environ Microbiol 57:2351-2359

Gaur R, Shani N, Jeet K, Johri BN, Rossi P, Aragno M (2004) Diacetylphloroglucinol-producing pseudomonads do not influence AM fungi in wheat rhizosphere. Curr Sci 86:433-457 
Giovannetti M, Mosse B (1980) An evaluation of techniques for measuring vesicular-arbuscular mycorrhizal infection in roots. New Phytol 124:221-230

Govindarajulu M, Pfeffer PE, Jin H, Abubaker J, Douds DD, Allen JW, Bücking H, Lammers PJ, Shachar-Hill Y (2005) Nitrogen transfer in the arbuscular mycorrhizal symbiosis. Nature 435:819-823. doi:10.1038/nature03610

Haas D, Défago G (2005) Biological control of soil-borne pathogens by fluorescent pseudomonads. Nat Rev Microbiol 3:307-319. doi:10.1038/nrmicro1129

Haas D, Keel C (2003) Regulation of antibiotic production in rootcolonizing Pseudomonas spp. and relevance for biological control of plant diseases. Annu Rev Phytopathol 41:117-153. doi:10.1146/annurev.phyto.41.052002.095656

Harrison MJ (2005) Signalling in the arbuscular mycorrhizal symbiosis. Annu Rev Microbiol 59:19-42. doi:10.1146/annurev.mi cro.58.030603.123749

Hoagland DR, Arnon DI (1950) The water-culture method for growing plants without soil. Circular 347. Agricultural Experiment Station, University of California, Berkeley

Hodge A (2001) Arbuscular mycorrhizal fungi influence decomposition of, but not plant nutrient plant capture from, glycine patches in soil. New Phytol 151:725-734. doi:10.1046/j.0028646x.2001.00200.x

Ianson DC, Linderman RG (1993) Variation in the response of nodulating pigeonpea (Cajanus cajan) to different isolates of mycorrhizal fungi. Symbiosis 15:105-119

Johnson D, Leake JR, Ostle N, Ineson P, Read DJ (2002) In situ (CO2)-C-13 pulse-labelling of upland grassland demonstrates a rapid pathway of carbon flux from arbuscular mycorrhizal mycelia to the soil. New Phytol 153:327-334. doi:10.1046/ j.0028-646X.2001.00316.x

Keel C, Schnider U, Maurhofer M, Voisard C, Burger D, Haas D, Défago G (1992) Suppression of root diseases by Pseudomonas fluorescens CHA0: importance of the bacterial secondary metabolite 2, 4-diacetylphloroglucinol. Mol Plant Microbe Interact 5:4-13

Kloepper JW (1993) Plant growth promoting rhizobacteria as biological control agents. In: Metting FB Jr (ed) Soil microbia ecology -applications in agricultural and environmental management. Marcel Dekker, New York, pp 255-274

Landa BB, Mavrodi OV, Raaijmakers JM, Gardener BBM, Thomashow LS, Weller DM (2002) Differential ability of genotypes of 2, 4-diacetylphloroglucinol-producing Pseudomonas fluorescens strains to colonize the roots of pea plants. Appl Environ Microbiol 68:3226-3237. doi:10.1128/ AEM.68.7.3226-3237.2002

Langmeier M, Oberson A, Kreuzer M, Frossard E (1998) N fertilizer efficiency of cattle manure. Part I: ${ }^{15} \mathrm{~N}$ labeling of cow excreta. First Symposium of the Competence Centre for Plant Sciences, 10 Dec, Zurich

Legendre P, Legendre L (1998) Numerical ecology. Second English edition. Elsevier, Amsterdam

Levy A, Chang BJ, Abbott LK, Kuo J, Harnett G, Inglis TJJ (2003) Invasion of spores of the arbuscular mycorrhizal fungus Gigaspora decipiens by Burkholderia spp. Appl Environ Microbiol 69:6250-6256. doi:10.1128/AEM.69.10.62506256.2003

Linderman RG (1988) Mycorrhizal interactions with the rhizosphere microflora: the mycorrhizospheric effect. Phytopathology 78:366-371

Linderman RG (2000) Effects of mycorrhizas on plant tolerance to disease. In: Kapulnik Y, Douds DD (eds) Arbuscular mycorrhizas: physiology of function. Kluwer, Dordrecht, pp 345-365

Mäder P, Vierheilig H, Streitwolf-Engel R, Boller T, Frey B, Christie $\mathrm{P}$, Wiemken A (2000) Transport of ${ }^{15} \mathrm{~N}$ from a soil compartment separated by a poly tetrafluoroethylene membrane to plant roots via the hyphae of arbuscular mycorrhizal fungi. New Phytol 146:155-161. doi:10.1046/j.1469-8137.2000.00615.x

Meyer JR, Linderman RG (1986a) Response of subterranean clover to dual inoculation with vesicular-arbuscular mycorrhizal fungi and a plant growth-promoting bacterium, Pseudomonas putida. Soil Biol Biochem 18:185-190. doi:10.1016/0038-0717(86)90025-8

Meyer JR, Linderman RG (1986b) Selective influence on populations of rhizosphere and rhizoplane bacteria and actinomycetes by mycorrhiza formed by Glomus fasciculatum. Soil Biol Biochem 18:191-196. doi:10.1016/0038-0717(86)90026-X

Oehl F, Sieverding E, Ineichen K, Mäder P, Boller T, Wiemken A (2003) Impact of land use intensity on the species diversity of arbuscular mycorrhizal fungi in agroecosystems of central Europe. Appl Environ Microbiol 69:2816-2824. doi:10.1128/ AEM.69.5.2816-2824.2003

Onishi T, Gall RS, Mayer ML (1975) An improved assay of inorganic phosphate in the presence of extralabile phosphate compounds: application to the ATPase assay in the presence of phosphocreatine. Anal Biochem 69:261-267. doi:10.1016/0003-2697(75) 90585-0

Paulitz TC, Linderman RG (1989) Interactions between fluorescent pseudomonads and VA mycorrhizal fungi. New Phytol 113:37-45. doi:10.1111/j.1469-8137.1989.tb02393.x

Phillips JM, Hayman DS (1970) Improved procedures for clearing roots and staining parasitic and vesicular-arbuscular mycorrhizal fungi for rapid assessment of infection. Trans $\mathrm{Br}$ Mycol Soc $55: 158$

Pielou EC (1984) The interpretation of ecological data: a data on classification and ordination. Wiley, New York

Raaijmakers JM, Weller DM (1998) Natural plant protection by 2,4diacetyl-phloroglucinol-producing Pseudomonas spp. in take-all decline soils. Mol Plant Microbe Interact 11:144-152. doi:10.1094/MPMI.1998.11.2.144

Raaijmakers JM, Bonsall RF, Weller DM (1999) Effect of population density of Pseudomonas fluorescens on production of 2, 4diacetylphloroglucinol in the rhizosphere of wheat. Phytopathology 89:470-475. doi:10.1094/PHYTO.1999.89.6.470

Raaijmakers JM, de Bruijn I, de Kock MJD (2006) Cyclic lipopeptide production by plant-associated Pseudomonas spp.: diversity, activity, biosynthesis, and regulation. Mol Plant Microbe Interact 19:699-710. doi:10.1094/MPMI-19-0699

Rainey PB (1999) Adaptation of Pseudomonas fluorescens to the plant rhizosphere. Appl Environ Microbiol 1:243-257. doi:10.1046/j.1462-2920.1999.00040.x

Ravnskov S, Nybore O, Jakobsen I (1999) Influence of an arbuscular mycorrhizal fungus on Pseudomonas fluorescens DF57 in rhizosphere and hyphosphere soil. New Phytol 142:113-122. doi:10.1046/j.1469-8137.1999.00374.x

Rezzonico F, Zala M, Keel C, Duffy C, Moënne-Loccoz Y, Défago $G$ (2007) Is the ability of biocontrol fluorescent pseudomonads to produce the antifungal metabolite 2, 4diacetylphloroglucinol really synonymous with higher plant protection? New Phytol 173:861-872. doi:10.1111/j.14698137.2006.01955.x

Rhodes LH, Gerdemann JW (1975) Phosphate uptake zones of mycorrhizal and non-mycorrhizal onions. New Phytol 75:555-561. doi:10.1111/j.1469-8137.1975.tb01419.x

Schnider-Keel U, Keel C, Blumer C, Troxer J, Défago G, Haas D (1995) Amplification of the housekeeping sigma factor in Pseudomonas fluorescens CHA0 enhances antibiotic production and improves biocontrol abilities. J Bacteriol 177:5387-5392

Schreiner RP, Mihara KL, McDaniel H, Bethlenfalvay GJ (1997) Mycorrhizal fungi influence plant and soil functions and interactions. Plant Soil 188:199-209. doi:10.1023/ A:1004271525014 
Schussler A, Schwarzott D, Walker C (2001) A new fungal phylum, the Glomeromycota: phylogeny and evolution. Mycol Res 105:1413-1421. doi:10.1017/S0953756201005196

Singh S, Kapoor KK (1998) Effects of inoculation of phosphate solubilizing microorganisms and an arbuscular mycorrhizal fungus on mungbean grown under natural soil conditions. Mycorrhiza 7:249-253. doi:10.1007/s005720050188

Smith FA, Read SE (1997) Structural diversity in (vesicular)arbuscular mycorrhizal symbiosis. New Phytol 137:373-388. doi:10.1046/j.1469-8137.1997.00848.x

Thomashow LS, Weller DM (1995) Plant microbe interact vol. 1. In: Stacey G, Keen N (eds) Current concepts in the use of introduced bacteria for biological disease control: mechanisms and antifungal metabolites. Chapman and Hall, New York, pp 187-235

Toljander JF, Artursson V, Paul LR, Janssom JK, Finlay RD (2006) Attachment of different soil bacteria to arbuscular mycorrhizal fungal extraradical hyphae is determined by hyphal vitality and fungal species. FEMS Microbiol Lett 254:34-40. doi:10.1111/ j.1574-6968.2005.00003.x

Toro M, Azcon R, Barea JM (1997) Improvement of arbuscular mycorrhiza development by inoculation of soil with phosphate solubilizing rhizobacteria to improve rock phosphate bioavailability (P-32) and nutrient cycling. Appl Environ Microbiol 63:4408-4412

Vázquez MM, César S, Azcón R, Barea JM (2000) Interactions between arbuscular mycorrhizal fungi and other microbial inoculants (Azospirillum, Pseudomonas, Trichoderma) and their effects on microbial population and enzyme activities in the rhizosphere of maize plants. Appl Soil Ecol 15:261-272. doi:10.1016/S0929-1393(00)00075-5

Vosátka M, Gryndler M (1999) Treatment with culture fractions from Pseudomonas putida modifies the development of Glomus fistulosum mycorrhiza and the response of potato and maize plants to inoculation. Appl Soil Ecol 11:245-251. doi:10.1016/ S0929-1393(98)00151-6

Watanabe FS, Olsen SR (1965) Test of an ascorbic acid method for determining phosphorus in water and $\mathrm{NaHCO}_{3}$ extracts from soil. Soil Sc Soc Am Proc 29:677-678

Weller DM, Landa BB, Mavrodi OV, Schroeder KL, De La Fuente L, Bankhead SB, Molar RA, Bonsall RF, Mavrodi DV, Thomashow LS (2007) Role of 2,4-diacetylphloroglucinol-producing fluorescent Pseudomonas spp. in the defense of plant roots. Plant Biol 9:4-20. doi:10.1055/s-2006-924473

Whipps JM (2001) Microbial interactions and biocontrol in the rhizosphere. J Exp Bot 52:487-511

Wyss P, Boller T, Wiemken A (1991) Phytoalexin response is elicited by a pathogen Rhizoctonia solani but not by mycorrhizal fungus (Glomus mosseae) in soybean roots. Experientia 47:395-399. doi:10.1007/BF01972082

Xavier LJC, Germida JJ (2003) Bacteria associated with Glomus clarum spores influence mycorrhizal activity. Soil Biol Biochem 35:471-478. doi:10.1016/S0038-0717(03)00003-8 